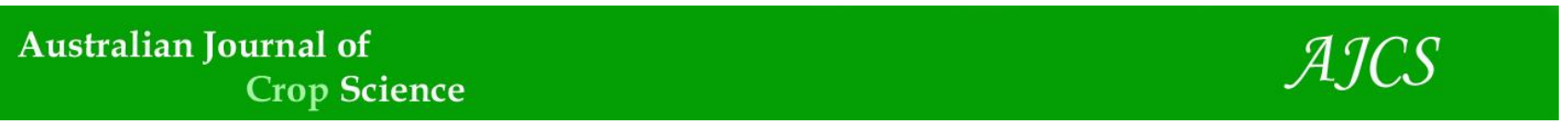

AJCS 14(10):1695-1700 (2020)

ISSN:1835-2707

doi: 10.21475/ajcs.20.14.10.p2848

\title{
Growth and quality of SJ-02 cocoa seedlings (Theobroma cacao L.) under different irrigation depths and cultivation containers
}

\author{
Vinicius de Souza Oliveira ${ }^{1}$, Stefany Sampaio Silveira ${ }^{2}$, Robson Prucoli Posse ${ }^{2}$, Laís Gertrudes Fontana Silva ${ }^{3}$, Valeria \\ Pancieri Sallin ${ }^{3}$, Gabriel Sossai Pancieri ${ }^{2}$, Matheus Pancieri Sellin ${ }^{2}$, Victor Luchi Guerra ${ }^{2}$, Carlos Alverto Spaggiari \\ Souza ${ }^{4}$, Geilson Silva Costa ${ }^{2}$, Moisés Zucoloto ${ }^{1}$, Edilson Romais Schmildt ${ }^{3}$ \\ ${ }^{1}$ Federal University of Espírito Santo - Center for Agricultural Sciences and Engineering, Alegre, Espírito Santo, Brazil \\ ${ }^{2}$ Federal Institute of Espírito Santo - Campus Itapina, Colatina, Espírito Santo, Brazil \\ ${ }^{3}$ Federal University of Espírito Santo - Center Noth of Espírito Santo, São Mateus, Espírito Santo, Brazil \\ ${ }^{4}$ Cacao Research Station “Filogônio Peixoto" - CEPLAC, Linhares, Espírito Santo, Brazil
}

\section{Abstract}

The study aimed to evaluate the growth and quality of SJ-02 cocoa seedlings under different irrigation depths and cultivation container sizes. The experiment was arranged as a completely randomized design, in a factorial scheme (4x3), where the first factor consisted of the application of four different irrigation depths $\left(6,10,12\right.$ and $\left.14 \mathrm{~mm} \mathrm{~d}^{-1}\right)$ and the second one was composed of three different cultivation containers (small, medium and large). Twelve treatments were evaluated with eight repetitions, totaling 96 plants in the experimental field. At 74 days after sowing, the leaf area, stem diameter, plant height, dry mass of the aerial part, dry mass of the root system, total dry mass and Dickson's quality index of all seedlings were analyzed. The $10.32 \mathrm{~mm} \mathrm{~d}^{-1}$ irrigation depth and the medium and large cultivation containers provided the highest quality in seedling production, being the most suitable ones. However, there was no interaction between the factors.

Keyword: Dickson's quality index, irrigation management, seedling quality.

Abbreviations: LA_Leaf Area; SD_stem diameter; PH_Plant Height; DMAP_Dry Mass of the Aerial Part; DMRS_Dry Mass of the Root System; TDM_Total Dry Mass; DQI_Dickson's Quality Index; SV_Source of Variation; DF_Degree of Freedom; AS_Average Square; CV_Coefficient of Variation.

\section{Introduction}

The cacao tree (Theobroma cacao L.) is a perennial species, belonging to the Malvaceae family, native to America, where it grows in a tropical climate (Lima et al., 2018). The main commercial interest of this species is the use of kernels as raw material mainly in the production of chocolate, in addition to jellies, juices, creams and in the cosmetics industry (Almeida and Valle, 2007). Brazil stands out as the sixth world producer of this crop, with a production of 250,308 tons in 2018 (Agrianual, 2017; IBGE, 2019).

To grow a successful perennial crop, it is essential that the plants have desired genetic characteristics, besides high quality seedlings (Souza Júnior, 2018). Among many factors that interfere with the quality of the seedlings, the amount of water applied and the volume of the cultivation container are very important (Silva et al., 2015). In relation to the cultivation container, those that present a larger volume need more space to be allocated in the nursery, in addition to requiring a greater amount of substrate, labor and transportation, increasing the seedling production costs (Almeida, 2008). On the other hand, those with less volume can limit the growth of roots causing stress to plants (Lisboa et al., 2012). For irrigation, it is essential to seek adequate management without overuse or lack of water, once water availability directly interferes with the physiological processes of plants (Silva et al., 2015). The water deficit causes the stomatal closure of the plants and this defense mechanism reduces transpiration to avoid water losses.
However, there are limitations in the absorption of $\mathrm{CO}_{2}$, which reflects less accumulation of photoassimilates (Taiz and Zeiger, 2009). On the other hand, excess water increases the chances of the appearance of diseases due to the favorable microclimate, allowing leaching of nutrients, increasing the expenditure on energy and fertilizers, besides generating socio-environmental issues with excessive water consumption (Lopes et al., 2005). Thus, the objective of this study was to evaluate the growth and quality of SJ-02 cocoa seedlings under four irrigation depths and three cultivation container sizes.

\section{Results and discussion}

After analysis of variance by the $F$ test $(p>0.05)$, it was observed that there was no statistical difference for the characteristics of leaf area (LA) and dry mass of the aerial part (DMAP) related to the applied irrigation depth, while significant differences were observed for plant height $(\mathrm{PH})$, stem diameter (SD) and Dickson's quality index (DQI) according to the cultivation container used. There was no significant effect between the irrigation depth and cultivation container factors (Table 1). 


\section{Morphological characteristics in the applied irrigation depth}

For the morphological characteristics according to the applied irrigation depth, it is possible to observe that there were no statistical differences for LA, with an average of $305.349 \mathrm{~cm}^{2}$ for all treatments (Fig. 1A). The SD presented an increasing linear adjustment with a coefficient of determination $\left(R^{2}\right)$ of 0.8557 (Figure 1B). PH had a quadratic behavior, with a height of $27.40 \mathrm{~cm}$ in the irrigation depth of $9.41 \mathrm{~mm} \mathrm{~d}^{-1}$ and $\mathrm{R}^{2}$ of 0.6926 (Fig. 1C).

There was no effect of treatments on LA and the adjustment based on SD was not conclusive for this characteristic, but the harmful effect of the lack and excess of water can be easily observed by reducing the growth and $\mathrm{PH}$. The water deficit leads the cells to dehydration, affecting innumerable physiological processes such as decreasing the turgor pressure. In addition, it can induce the formation of free radicals that, in excess, affect the DNA, prevent the synthesis of proteins and damage the photosynthetic pigments having direct effect on the photosynthesis process, considerably impairing vegetative growth (Taiz et al., 2017). Water excess leads the plant to a level of lack of oxygen, restraining the roots to have enough energy to supply the demand for the physiological processes necessary for the proper functioning of the aerial part, in addition, the scarcity of oxygen induces the formation of abscisic acid ( $A B A$ ) promoting stomatal closure and limiting photosynthesis (Taiz and Zeiger, 2009).

\section{Biomass characteristics in the applied irrigation depth}

The behavior of the biomass characteristics in relation to the applied irrigation depths is shown in Fig. 2. For the DMAP, it was not possible to adjust an equation, being the average of 2.269 g representative for all treatments (Fig. 2A). The DMRS showed a quadratic adjustment, with a maximum point of $0.97 \mathrm{~g}$ in the irrigation depth of $9.95 \mathrm{~mm} \mathrm{~d}^{-1}$ and $\mathrm{R}^{2}$ of 0.5556 (Fig. 2B). The TDM had a quadratic effect with greater mass accumulation of $3.27 \mathrm{~g}$ in the irrigation depth of $10.20 \mathrm{~mm}$ $\mathrm{d}-1$ and $\mathrm{R}^{2}$ of 0.9205 (Fig. 2C). The accumulation of total biomass of the seedlings measured by the TDM was severely affected by the water deficit generated by the smallest irrigation depths. In addition, there was also a reduction in the values of this characteristic observed in the largest ones, attesting that the excess water also had a negative effect on the accumulation of biomass by seedlings. This occurs because the different irrigation depths have an effect on the transpiration of plants, under which conditions there are changes in their natural physiological processes related to gas exchange (Freitas et al., 2011). Under water deficit, plants have a stomatal closure as a mechanism to decrease water loss, reducing transpiration. However, this mechanism limits $\mathrm{CO} 2$ absorption, reducing the accumulation of photoassimilates (Taiz and Zeiger, 2009). Water excess creates an environment of oxygen scarcity in the roots, leading the plant to change its metabolism, replacing the respiration process with fermentation, which can cause energy depletion, and consequently, limitations in the growth and development of plants, directly reflecting the reduction of biomass (Martinazzo et al., 2012; Mazzuchelli et al., 2014; Posse et al., 2019). Thus, abiotic factors, such as good water condition, provide the plant with an increase in the rate of transpiration that implies an increase in dry mass production (Lopes et al. 2011).

\section{Quality characteristic in the applied irrigation depth}

The quality of seedlings attested by the DQI showed a quadratic adjustment in relation to the applied irrigation depth, with a higher index of 0.39 in the $10.32 \mathrm{~mm} \mathrm{~d}^{-1}$ depth and $R^{2}$ of 0.7523 (Fig. 3). The DQI is an important tool to define seedling quality standards, once its formula includes morphological and biomass characteristics (Gomes, 2001). Thus, the higher the DQI values, the higher the quality standard of the analyzed seedlings (Costa et al., 2011).

\section{Morphological characteristic, biomass and quality in cultivation container}

Table 2 demonstrate that the SJ-02 cocoa seedlings grown in the three different containers showed a tendency to increase the stem diameter (SD) and the Dickson quality index (DQI) with the increase in the volume of the container. For plant height $(\mathrm{PH})$, this trend was reversed, with the highest averages with the decreasing of the container volume. For the leaf area (LA), dry mass of aerial part (DMAP) and total dry mass (TDM) the average values of the three types of container were statistically equal.

In relation to $\mathrm{PH}$, the highest value was found in the small cultivation container, being statistically higher than the averages found in the medium and large ones, which presented similar results. According to Silva et al. (2015), the highest height is used by nurserymen in selecting seedlings for field planting. However, this characteristic should not be used only as a criterion for evaluating seedling quality as it may not express greater vigor.

About the SD, the medium and large containers showed equal results with a statistical average superior to the small one. According to Gomes (2001), this characteristic may reflect as greater survival of seedlings when transplanted to the field. In agreement with this statement, it is possible to observe that the same containers that have better averages for SD also have higher DQI values, which indicates that these seedlings are more robust, being able to have better adaptation to field conditions. It offers a higher survival rate, besides the DQI represents the union of all the characteristics evaluated in this study and can more accurately define the quality of the seedlings (Silva et al., 2015; Dickson et al., 1960).

In the view of the analyzed data, it is possible to say that there was interference both in the applied irrigation depth and in the size of the cultivation containers that the SJ-02 cocoa seedlings were submitted. However, there was no interaction between these two factors. The irrigation depths between 9.41 and $10.32 \mathrm{~mm} \mathrm{~d}^{-1}$ provided higher values for the analyzed characteristics, with the irrigation depths of $10.32 \mathrm{~mm} \mathrm{~d}^{-1}$ being the most indicated one for presenting higher DQI, a characteristic that defines quality of seedlings. In relation to the cultivation container, the ones that provided better quality of the seedlings were those of medium and large size, thus being the most suitable for this cultivar.

\section{Materials and methods}

\section{Location of the experiment}

The study took place at the Federal Institute of Espírito Santo, Campus Itapina, in Colatina, northwest of the State of Espírito Santo, Brazil, located with geographical coordinates 
Table 1. Summary of the analysis of variance with the source of variation (SV), degree of freedom (DF), average square (AS) and coefficient of variation (CV) for the characteristics: plant height (PH), stem diameter (SD), leaf area (LA), dry mass of the aerial part (DMAP), dry mass of the root system (DMRS), total dry mass (TDM) and Dickson's quality index (DQI).

\begin{tabular}{|c|c|c|c|c|c|c|c|c|}
\hline \multirow{2}{*}{ SV } & \multirow{2}{*}{ DF } & \multicolumn{3}{|c|}{ AS } & \multirow[b]{2}{*}{ DMAP } & \multirow[b]{2}{*}{ DMRS } & \multirow[b]{2}{*}{ TDM } & \multirow[b]{2}{*}{ DQI } \\
\hline & & $\mathrm{PH}$ & SD & LA & & & & \\
\hline ID & 3 & $36.71^{*}$ & $2.968^{*}$ & $8581.3^{\text {ns }}$ & $0.511^{\text {ns }}$ & $2.451^{*}$ & $1.968^{*}$ & $0.139^{*}$ \\
\hline CC & 2 & $62.91^{*}$ & $2.001^{*}$ & $13118.9^{\text {ns }}$ & $0.260^{\mathrm{ns}}$ & $0.203^{\mathrm{ns}}$ & $0.876^{\mathrm{ns}}$ & $0.052^{*}$ \\
\hline IDxCC & 6 & $3.56^{\mathrm{ns}}$ & $0.403^{\mathrm{ns}}$ & $8461.7^{\text {ns }}$ & $0.062^{\text {ns }}$ & $0.121^{\mathrm{ns}}$ & $0.123^{\mathrm{ns}}$ & $0.007^{\text {ns }}$ \\
\hline RES & 84 & 9.73 & 0.269 & 6998.1 & 0.366 & 0.089 & 0.422 & 0.012 \\
\hline Total & 95 & & & & & & & \\
\hline $\mathrm{CV}^{1}(\%)$ & & 11.9 & 10.78 & 27.4 & 26.66 & 42.15 & 21.8 & 32.91 \\
\hline
\end{tabular}
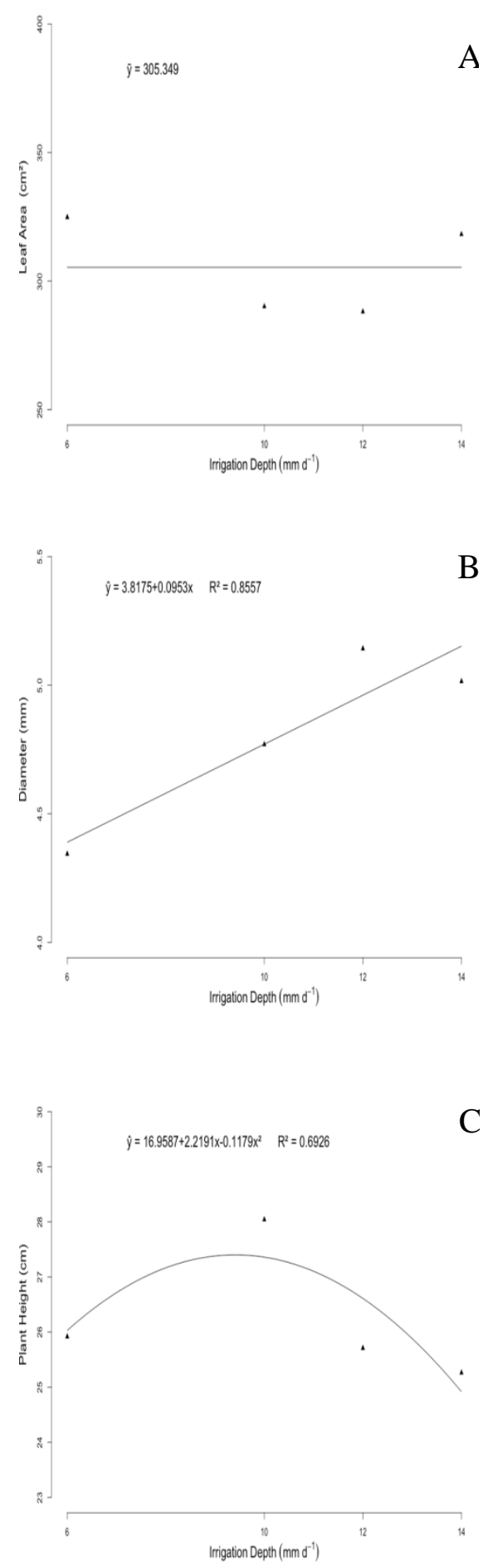

Fig 1. Effect of the application of different irrigation depths on the leaf area (A), stem diameter (B) and plant height (C) of SJ-02 cocoa seedlings. 
Table 2. Average values of plant height (PH), stem diameter (SD), leaf area (LA), dry mass of the aerial part (DMAP), dry mass of the root system (DMRS), total dry mass (TDM) and Dickson's quality index (DQI) in three containers of SJ-02 cocoa seedlings.

\begin{tabular}{llllllll}
\hline CONTAINER & PH & SD & LA & DMAP & DMRS & TDM & DQI \\
\hline Small & $27.65 \mathrm{a}$ & $4.52 \mathrm{~b}$ & $291.61 \mathrm{a}$ & $2.16 \mathrm{a}$ & $0.63 \mathrm{a}$ & $2.79 \mathrm{a}$ & $0.28 \mathrm{~b}$ \\
Medium & $26.18 \mathrm{~b}$ & $4.97 \mathrm{a}$ & $328.60 \mathrm{a}$ & $2.31 \mathrm{a}$ & $0.71 \mathrm{a}$ & $3.02 \mathrm{a}$ & $0.34 \mathrm{a}$ \\
Large & $24.85 \mathrm{~b}$ & $4.94 \mathrm{a}$ & $295.83 \mathrm{a}$ & $2.32 \mathrm{a}$ & $0.79 \mathrm{a}$ & $3.11 \mathrm{a}$ & $0.36 \mathrm{a}$ \\
\hline \multicolumn{2}{l}{ Averages followed by the same letter between columns do not differ by the ScottKnott test at 5\% probability } & & &
\end{tabular}

Averages followed by the same letter between columns do not differ by the ScottKnott test at $5 \%$ probability.
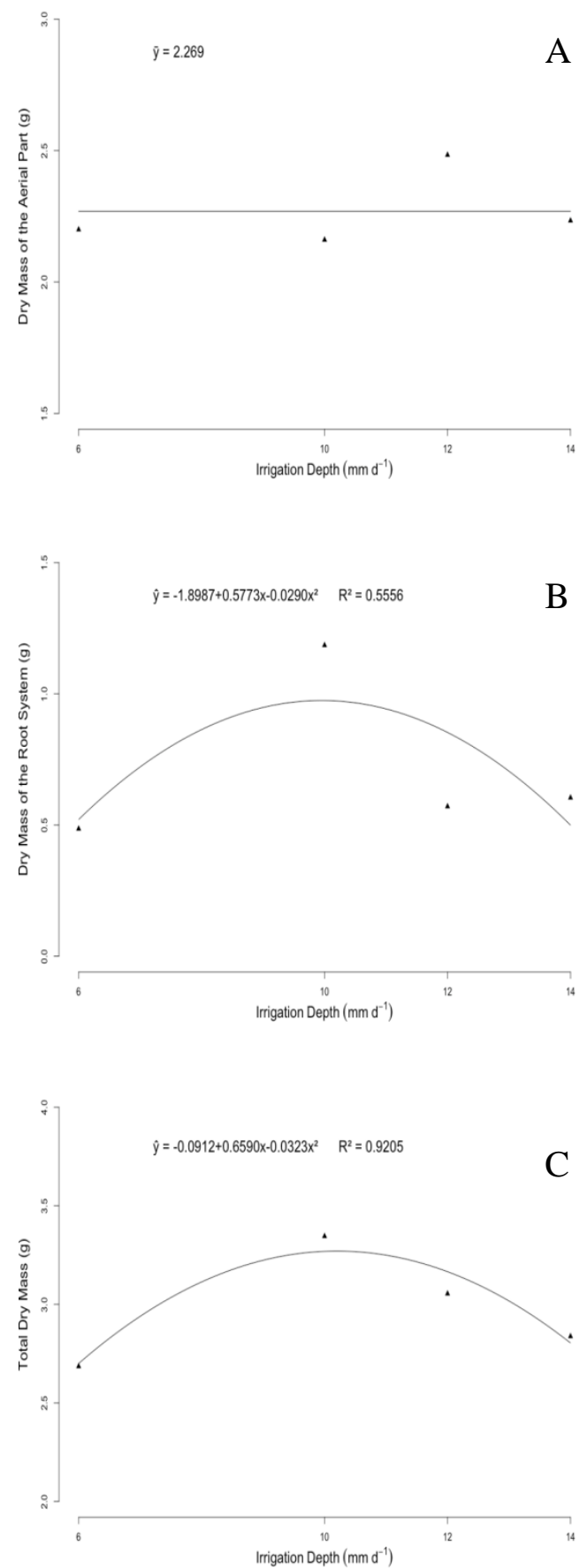

Fig 2. Effect of the application of different irrigation depths on the dry mass of the aerial part (A), dry mass of the root system (B) and total dry mass (C) of SJ-02 cocoa seedlings. 


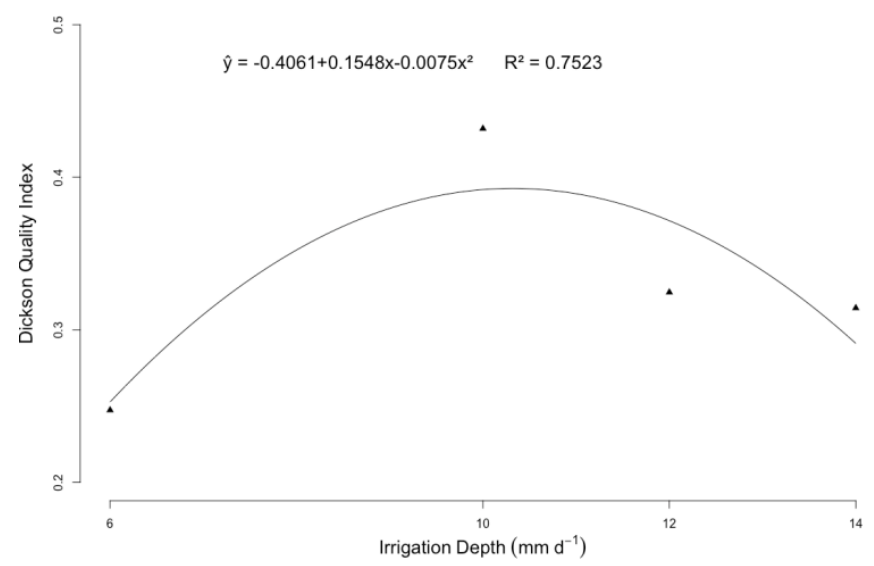

Fig. 3. Effect of the application of different irrigation depths on Dickson's quality index of SJ-02 cocoa seedlings.

of $19^{\circ} 32^{\prime} 22^{\prime \prime}$ south latitude and $40^{\circ} 37^{\prime} 50$ " west longitude, from October 1st to December 13th, 2018. The region is characterized by the tropical climate Aw according to the Köppen classification with rainy summer and dry winter (Alvares et al., 2014).

\section{Experimental design}

To carry out the experiment, four individual environments with dimensions of 2.20 in length and 1.10 in width were set up, covered with transparent plastic canvas. Each individual environment consisted of six GREEN MIST anti-droplet nebulizers (NaanDanJain ) located $1 \mathrm{~m}$ above the seedlings and spaced $0.8 \mathrm{~m}$ apart. Irrigation was performed with 0.5 $\mathrm{hp}$ centrifugal pumps, with an operating pressure of $2 \mathrm{kgf}$ $\mathrm{cm}^{-2}$, controlled individually and electronically, with irrigation distributed for 10 hours a day.

The design was completely randomized in a factorial scheme $(4 \times 3)$. The first factor was the application of four different irrigation depths, which are: $6,10,12$ and $14 \mathrm{~mm} \mathrm{~d}^{-1}$. The second factor comprised of three different cultivation containers, being polypropylene bags with dimensions of 10 $\times 20 \mathrm{~cm}$ (small), $15 \times 25 \mathrm{~cm}$ (medium) and $13 \times 35$ (large). Twelve treatments were evaluated, with eight repetitions, totaling 96 plants in the experimental field.

\section{Plant material}

The seeds used were SJ-02 cocoa obtained from completely ripe fruits, which had the mucilage removed by rubbing. To prepare the seedlings, the different crop containers were filled with commercial substrate Tropstrato $\mathrm{HT}^{\circ}$ Vegetables plus Osmocote Plus $15-9-12(3 \mathrm{M})$, in the dosage of $12 \mathrm{~kg} /$ $\mathrm{m}^{3}$ with the following chemical composition: $\mathrm{N}=15 \%,(7 \%$ ammoniacal and $8 \%$ nitrate), $\mathrm{P}_{2} \mathrm{O}_{5}=9 \%, \mathrm{~K}_{2} \mathrm{O}=12 \%, \mathrm{Mg}=$ $1.3 \%, \mathrm{~S}=5.9 \%, \mathrm{Cu}=0.05 \%, \mathrm{Fe}=0.46 \%, \mathrm{Mn}=0.06 \%$ and $\mathrm{Mo}$ $=0.02 \%$. One seed per container with a depth of approximately $2 \mathrm{~cm}$ was used.

\section{Assessment of characteristics}

At 74 days after sowing, in all seedlings, the following morphological characteristics were evaluated: leaf area (LA), measured with a leaf area meter LI-COR model LI-3100C, in $\mathrm{cm}^{2}$; stem diameter (SD) measured $2 \mathrm{~cm}$ above the edge of the cultivation container, in $\mathrm{mm}$; plant height $(\mathrm{PH})$, determined with a graduated ruler, in $\mathrm{cm}$, measured from the stem to the apical bud, biomass characteristics: dry mass of the aerial part (DMAP), dry mass of the root system (DMRS) and total dry mass (TDM), expressed in $g$ and the quality characteristic defined by Dickson's quality index (DQI) according to Dickson et al. (1960) through the equation:

$$
\mathrm{DQI}=\frac{\mathrm{TDM}}{\frac{\mathrm{PH}}{\mathrm{SD}}+\frac{\mathrm{DMAP}}{\mathrm{DMRS}}}
$$

To obtain DMAP and DMRS, the seedlings were dried in a forced air oven at a temperature of 65 ㅇ for 72 hours and weighed on a precision scale of $0.001 \mathrm{~g}$. TDM was defined as the product of the sum of DMAP and DMRS.

\section{Statistical analyses}

Statistical analyzes were performed based on the outline and scheme adopted. All data were subjected to analysis of variance by the $\mathrm{F}$ test at $5 \%$ probability. The effect of the irrigation depth on the evaluated characteristic was tested by regression analysis using the $\mathrm{F}$ test at $5 \%$ probability. The best equation was adjusted to explain each effect. The maximum points were defined from the primary derivative of the regression equation. The influence of different cultivation containers on the characteristics evaluated was tested by Scott Knott's averaging cluster test at 5\% probability. All statistical analyzes were performed using the $R$ software ( $R$ Core Team, 2019), through commands developed for the data package ExpDes.pt version 1.2 (Ferreira et al., 2010).

\section{Conclusion}

Both the irrigation depth and the volume of the container significantly interfered with the growth and quality of the SJ02 cocoa seedlings. However, there was no interaction between the factors. The $10.32 \mathrm{~mm} \mathrm{~d}-1$ irrigation depth and medium and large cultivation containers are the most suitable for this cultivar because it provides more quality in the production of seedlings. 


\section{References}

Agrianual (2017) Anuário da Agricultura Brasileira. São Paulo: FNP, Consultoria e Comércio. 315-320.

Alvares CA, Stape JL, Sentelhas PC, Gonçalves JLM, Sparovek G (2014) Köppen's climate classification map for Brazil. Meteorologische Zeitschrift. 22: 711-728.

Almeida AAF, Valle RR (2007) Ecophysiology of the cacao tree. Brazilian Journal of Plant Physiol. 19: 425-448.

Almeida MS (2008) Desenvolvimento de mudas de tamarindeiro: tamanhos de recipiente, substratos, peso de sementes e profundidades de semeadura. 2008. $42 \mathrm{f}$. Dissertação (Mestrado em Agronomia) Universidade Federal de Uberlândia, Uberlândia, Brazil.

Costa E, Durante LGY, Nagel PL, Ferreira CR, Santos A (2011) Qualidade de mudas de berinjela submetida a diferentes métodos de produção. Ciênc. Agron. 42: 1017-1025.

Dickson A, Leaf AL, Hosner JF (1960) Quality appraisal of white spruce and white pine seedling stock in nurseries. Forest Chronicles. 36: 10-13.

Ferreira EB, Cavalcanti PP, Nogueira DA (2018) Package 'ExpDes.pt'.

Freitas CAS, Silva ARA, Bezerra FML, Lacerda CF, Pereira Filho JV, Sousa GG (2011) Produção de matéria seca e trocas gasosas em cultivares de mamoneira sob níveis de irrigação. Rev. bras. eng. agríc. ambient. 15: 1168-1174.

Gomes JM (2001) Parâmetros morfológicos na avaliação da qualidade de mudas de Eucalyptus grandis, produzidas em diferentes tamanhos de tubete e de dosagens de N-P-K. 2001. 126 f. Tese (Doutorado em Ciência Florestal) Universidade Federal de Viçosa, Viçosa, Brazil.

IBGE (2018) Instituto Brasileiro de Geografia e Estatistica. Statistics on agricultural production. Available: https:// sidra.ibge.gov.br/

Lima SS, Spaggiari CA, Patrocínio NGRB, Silva RA, Santos RSG, Gramacho KP (2018) Favorabilidade, distribuição e prevalência da vassoura-de-bruxa do cacaueiro no estado do Espírito Santo, Brasil. Agrotrópica. 30: 5-14.
Lisboa AC, Santos OS, Oliveira Neto SN, Castro DN, Abreu AHM (2012) Efeito do volume de tubetes na produção de mudas de Calophyllum brasiliense e Toona ciliata. Rev. Árvore. 36: 603-609.

Lopes JLW, Guerrini IA, Saad JCC (2005) Efeitos de lâminas de irrigação na produção de mudas de Eucalyptus grandis W. (HILL EX. MAIDEN) em substrato de fibra de coco. Irriga: 10: 23-134.

Lopes OD, Kobayashi MK, Oliveira FG, Alvarenga ICA, Martins ER, Corsato CE (2011) Determinação do coeficiente de cultura (Kc) e eficiência do uso de água do alecrimpimenta irrigado. Rev. bras. eng. agríc. ambient. 15: 548553.

Martinazzo EG, Perboni AT, Oliveira PV, Bianchi VJ, Bacarin MA (2013) Atividade fotossintética em plantas de ameixeira submetidas ao déficit hídrico e ao alagamento. Ciênc. Rural. 43: 35-41.

Mazzuchelli EL, Souza GM, Pacheco AC (2014) Rustificação de mudas de eucalipto via aplicação de ácido salićlico. Pesqui. Agropecu. Tropl. 44: 443-450.

Posse RP, Partelli RL, Oliveira VS, Trindade IM, Silveira SS, Silva SMFS, Posse SCP, Souza CAS, Schmildt O, Schmildt ER (2019) Análise morfológica de mudas de cacaueiro cultivar CCN51 sob diferentes lâminas de irrigação. Int. J. Dev. Res. 9: 29211-29215.

R Core Team (2020) R: A language and environment for statistical computing. R Foundation for Statistical Computing, Vienna, Austria.

Silva CJ, Silva CA, Freitas CA, Golynski A, Golynski AA (2015) Produção e crescimento de mudas de baruzeiro em função de recipientes e lâminas de irrigação. Irriga. 20: 652-666.

Souza Júnior JO (2018) Cacau: cultivo, pesquisa e inovação. Ilhéus, BA: Editus.

Taiz L, Zeiger E (2009) Fisiologia vegetal (4th ed.) Porto Alegre: Artmed.

Taiz L, Zeiger E, Moller IM, Murphy A (2017) Fisiologia e desenvolvimento vegetal (6th ed.). Porto Alegre: Artmed. 